\title{
Identifikasi Air Tanah Daerah Agrotechno Park Cangar Batu Jawa Timur Berdasarkan Metode Geolistrik Resistivitas
}

\author{
Siti Ainur Rohmah, ${ }^{1, *}$ Sukir Maryanto, ${ }^{2}$ dan Adi Susilo ${ }^{2}$ \\ ${ }^{1}$ Program Studi Magister Ilmu Fisika, Fakultas MIPA, Universitas Brawijaya, Jalan Veteran, Malang, 65145 \\ ${ }^{2}$ Jurusan Fisika, Fakultas MIPA, Universitas Brawijaya, Jalan Veteran, Malang, 65145
}

Intisari

Identifikasi air tanah telah dilakukan di daerah Agrotecnopark Cangar dengan menggunakan metode geolistrik resistivitas. Akuisisi data dilakukan menggunakan konfigurasi mapping dipole-dipole sebanyak 11 line yang terbagi menjadi 2 wilayah. Inversi dilakukan terhadap data hasil akuisisi menggunakan software Res2dinv. Inversi data menghasilkan distribusi nilai resistivitas terhadap kedalaman penetrasi secara lateral struktur bawah permukaan yang disajikan dalam bentuk 2D dan 3D. Berdasarkan hasil inversi data diketahui bahwa lapisan bawah permukaan daerah penelitian memiliki resistivitas bernilai tinggi. Wilayah 1 (AL01-AL05) memiliki resistivitas rendah yaitu antara 100-500 Ohm.m. berada pada kedalaman 5 meter di bawah permukaan tanah. Lapisan tersebut diduga sebagai lapisan yang mengandung air sehingga dapat diketahui bahwa wilayah 1 memiliki potensi air tanah yang rendah. Sedangkan pada wilayah 2 (AL06-AL11) lapisan bawah pemukaan didominasi oleh lapisan yang memiliki resistivitas tinggi yaitu $>1000$ Ohm.m. nilai tersebut menunjukkan bahwa wilayah ini tidak memiliki potensi air tanah.

\begin{abstract}
The study of groundwater has been done at Agrotecnopark Cangar using resistivity method. Data acquisition were performed by using dipole-dipole mapping configuration along 11 lines in 2 regions. Inversion method is carried out on the acquisition data using Res2dinv software. The result of inversion is distributed resistivity value in depth laterally sections. They represents subsurface structure from each line in 2D and 3D form. Based on result known in the research area dominated by high resistivity. The region 1 (AL $01-05$ ) has low resisistivity in ranged 100-500 Ohm.m. which their depth arround 5 meters below ground surface. The resistivity range is suspected as the water-content layer so the layer has a low groundwater potential for region 1 . While in region 2 (AL06 - AL11) has resistivity dominated by high resistivity $>1000$ Ohm.m. The value indicates in region 2 has no potential for groundwater.
\end{abstract}

KATA KUNCI: groundwater, Resistivity, Agrotechnopark http://dx.doi.org/10.12962/j24604682.v14i1.3106

\section{PENDAHULUAN}

Agrotechno Park merupakan area yang berada di bawah kaki Gunungapi Arjuno-Welirang. Agrotechno Park masih dalam proses pengembangan lebih lanjut dimana akan dibangun berbagai fasilitas antara lain peternakan, perkebunan, tempat wisata, dan fasilitas penunjang pendidikan seperti laboratorium alam. Salah satu kebutuhan dalam proses pengembangan dan pengelolaan fasilitas tersebut adalah kebutuahan air [1]. Oleh karena itu faktor ketersediaan sumber daya air di daerah Agrotechno Park merupakan faktor utama yang perlu diperhatikan dalam pengembangan daerah tersebut.

Ketersediaan sumber daya air harus mampu mencukupi kebutuhan air. Kebutuhan air dapat dipenuhi dari permukaan tanah seperti sungai dan danau serta dapatjuga diperoleh dari bawah permukaan tanah yang disebut sebagai air tanah. Air-

*E-MAIL: sainurrohmah@gmail.com tanah memiliki kualitas lebih tinggi daripada air permukaan karena air permukaan sering tercemar oleh aktivitas antropogenik $[2,3]$. Oleh sebab itu, Dalam penggunaanya air tanah lebih dipertimbangkan sebagai sumber air dari pada air permukaan.

Keberadaan air tanah pada suatu wilayah dapat diketahui dengan melakukan penyelidikan struktur bawah permukaan tanah. Penyelidikan tersebut dapat dilakukan dengan menggunakan metode geolistrik [3-7]. Metode tersebut dipilih karena biaya yang dikeluarkan relatif rendah serta tidak merusak medium dan lingkungan sekitar namun hasilnya bisa dianalisis untuk mengetahui keberadaan lapisan air tanah $[3,8,9]$.

Metode geolistrik merupakan metode aktif yang bekerja dengan mengijeksikan arus listrik kepermukaan bumi melalui elektroda arus yang kemudian direspon oleh elektroda potesial $[4,7]$. Secara umum metode ini memanfaatkan resistivitas batuan yang berbeda-beda. Data yang diperoleh akan diinversi sehingga dapat menunjukan struktur bawah permukaan dalam bentuk penampang $2 \mathrm{D}$.

Berdasarkan uraian yang telah disampaikan mengenai ur- 


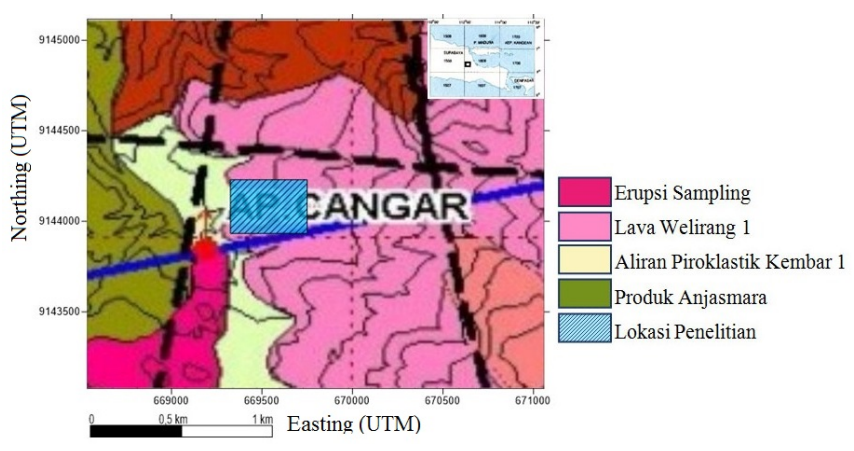

Gambar 1: Peta geologi daerah Cangar (modifikasi [11, 12]).

gensi kebutuhan air di daerah penelitian maka dilakukan penelitian untuk mengidentifikasi air tanah telah di daerah Agrotecno Park Cangar Batu Jawa Timur dengan menggunakan metode geolistrik resistivitas.

\section{Geologi regional daerah penelitian}

Wilayah Agrotechno Park berlokasi di kawasan Taman Hutan Raya R. Soeryo, Cangar, Sumber Brantas, Kota Batu. Daerah ini terletak diantara rangkaian gunungapi Arjuno-Welirang yang masih aktif. Geologi daerah Agrotechno Park terbentuk akibat dari aktifitas gunungapi Arjuno-Welirang berupa batuan vulkanik kuarter, lava, and piroklastik [10]. Produk aktifitas gunungapi tersebut secara khusus terdiri dari beberapa satuan yaitu satuan erupsi sampling, lava Welirang 1, aliran piroklastik Kembar 1, dan Produk Anjasmara. Kondisi geologi regional pada wilayah penelitian ditinjukkan oleh Gambar 1.

Produk aktifitas gunungapi Arjuno-Welirang berupa breksi gunungapi, lava, bresi tufan dan tuf. Breksi gunungapi berbutir pasir-bom serta memiliki komponen andesit, basal, batuapung, obsidian, mineral terang dan kaca gunungapi dengan masadasar tuf pasiran. Lava bersusunan andesit-basalt berwarna abu-abu, porfiritik, masif, terdiri dari mineral plagioklas, piroksen, olivindan mineral sekunder berupa mineral lempung dan oksida besi. Breksi tufan berbutir pasir kasarbom, serta berkomponen andesit, basal, batuapung, obsidian, porfiri, kaca gunungapi dan mineral hitam bermasadasar tuf pasiran. Tuf berbutir pasir kasar hingga halus berupa mineral terang, batu apung dengan tebal puluhan centimeter [12].

\section{METODE PENELITIAN}

Akuisisi data dilakukan pada bulan Juli di wilayah Agrotechno Park. Pengambilan data dilakukan sesuai dengan desain survei yang ditunjukan pada Gambar 2. Desain survei dibuat berdasarkan pemilihan wilayah yang mewakili keadaan bawah tanah Agrotechno Park. Berdasarkan desain survei akuisisi dilakukan pada 2 wilayah. Pembagian wilayah penilitian ini didilakukan karena adanya perbedaan topografi dimana wilayah 1 lebih tinggi dari wilayah 2. Selain itu morfologi wilayah di antara kedua wilayah tersebut berbatu, curam dan terdapat kolam yang tidak memungkinkan adanya

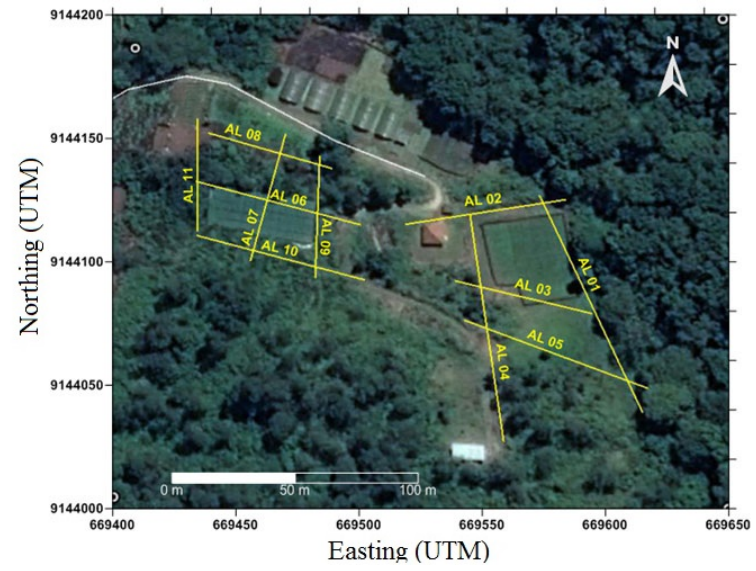

Gambar 2: Desain lintasan akuisisi survei geolistrik mapping di area Agrotechno Park Cangar.

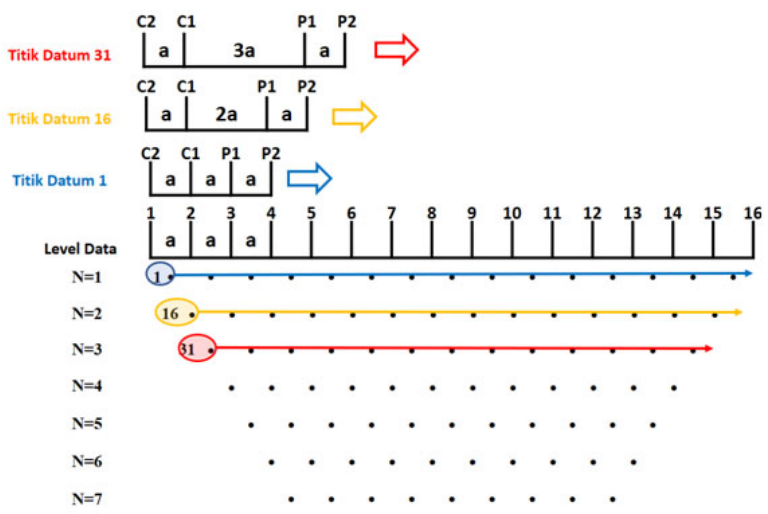

Gambar 3: Konfigurasi dipole-dipole.

line akuisisi. Jumlah line pada dua wilayah terdiri dari 11 line, dimana Setiap wilayah terdiri dari beberapa line yang saling berpotongan. Wilayah pertama terdiri dari 5 line yaitu AL01, AL02, AL03, AL04, dan AL05. Area kedua terdiri dari 6 line yaitu AL06, AL07, AL08, AL09, AL10, dan AL11.

Akuisisi data dilakukan menggunakan Resistivity Meter OYYO tipe McOhm-EL. Elektroda yang digunakan disusun berdasarkan kofigurasi dipole-dipole pada Gambar 3 dengan C1 dan C2 sebagai elektroda arus sedangkan P1 dan P2 sebagai elektroda potensial. Berdasarkan Gambar 2 bentangan yang diambil disesuaikan dengan panjang lintasan yaitu antara 60-100 m. Jarak antar elektroda adalah $5 \mathrm{~m}$. Paramater yang terukur yang diperoleh pada proses akuisisi data antara lain berupa nilai arus injeksi, beda potensial, resistansi dan jarak antar elektroda. Selain itu ditentukan pula koordinat GPS dari tiap datum pada setiap line akuisisi. Posisi koordinat tersebut akan digunakan dalam pengolahan data dan pemodelan 3D.

Parameter-parameter yang telah diperoleh dari akuisisi data dilanjutkan ke tahap pengolahan data. Pengolahan data ini bertujuan untuk menentukan nilai resistivitas semu. Nilai resistivitas semu diperoleh berdasarkan rumus [13],

$$
\rho_{a}=K \frac{\Delta V}{I}
$$




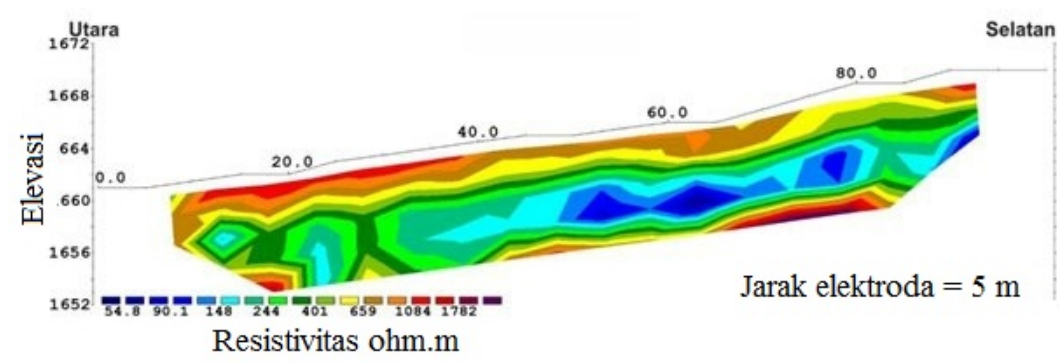

(a) line AL 01

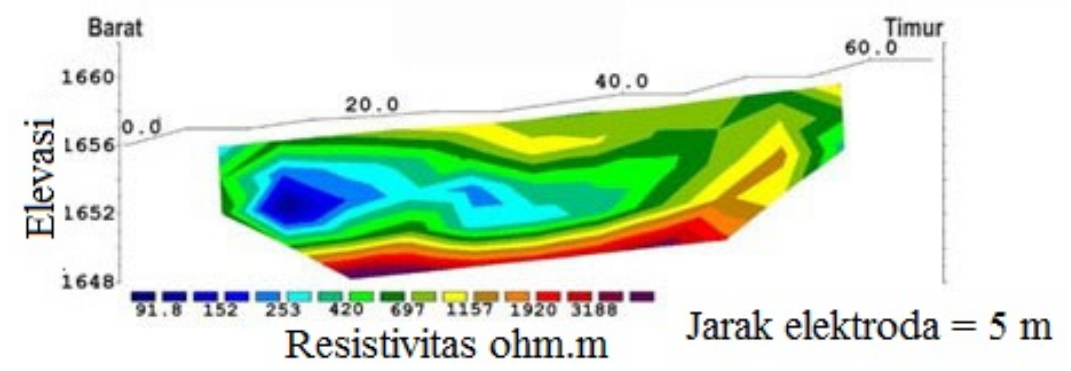

(b) line $\mathrm{AL} 02$

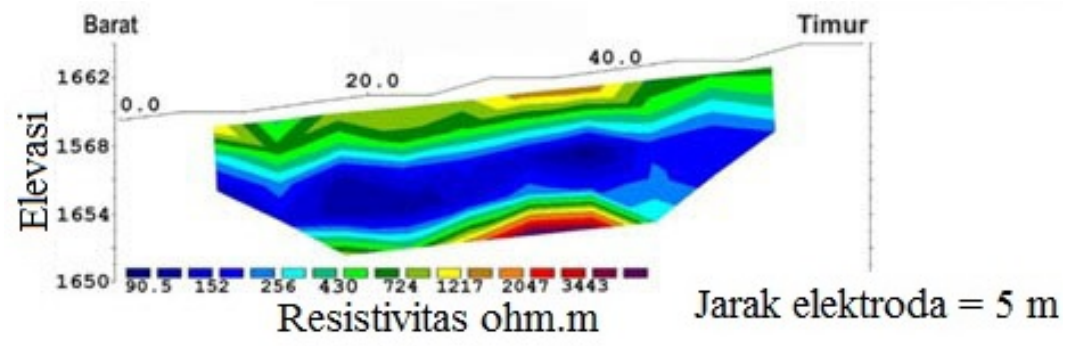

(c) line $\mathrm{AL} 03$

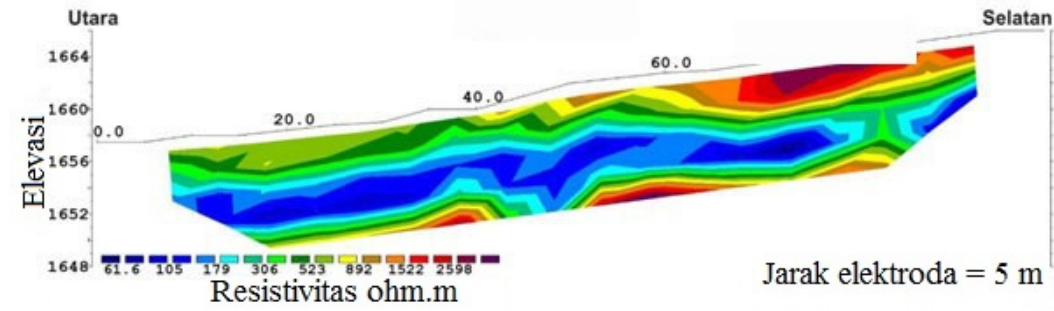

(d) line AL 04

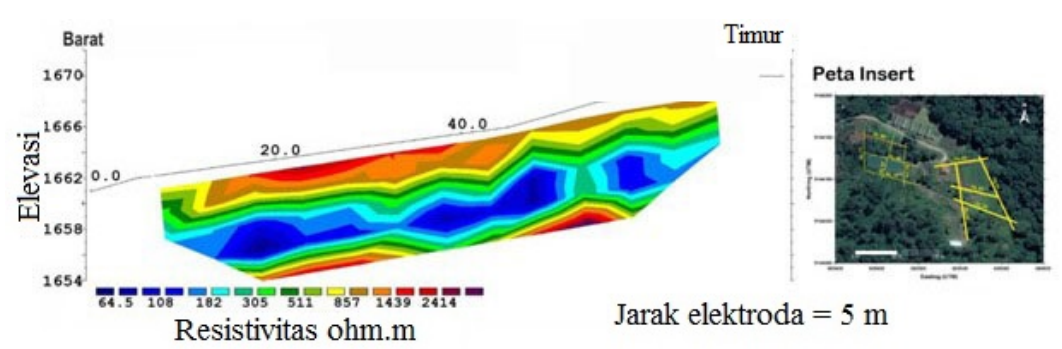

(e) line AL 05

Gambar 4: Model 2D hasil inversi data pada wilayah 1. 
dengan $\rho_{a}=$ resistivitas semu (ohm.m), $\mathrm{K}=$ faktor geometri, $\mathrm{V}=$ beda potensial (volt), $\mathrm{I}=$ kuat arus yang melalui bahan (ampere).

Selanjutnya dilakukan proses inversi data dengan metode least square inversion menggunakan software Res2dinv [4$6,14]$. Proses inversi ini dilakukan untuk menghilangkan efek geometris sehingga diperoleh nilai resistivitas sesungguhnya dari masing-masing line [5]. Hasil yang diperoleh disajikan dalam model penampang 2D. Model penampang tersebut berupa kontur distribusi nilai resistivitas terhadap kedalaman penetrasinya secara lateral struktur bawah permukaan dari masing-masing line [4, 6]. Interpretasi data dilakukan dengan menentukan kontras resistivitas batuan secara kuantitatif berdasarkan model 2D. Selain itu mengacu informasi geologi regional pada area penelitian kontras resistivitas hasil model 2D juga diinterpretasi secara kualitatif. Selanjutnya, dilakukan tomografi 3D. Tomografi 3D digunakan untuk memecahkan masalah yang berkaitan dengan hasil-hasil kontras densitas 2D dari masing-masing line seperti kesinambungan perlapisan tiap-tiap line dan penentuaan struktur yang berkembang di area penelitian [15].

\section{HASIL DAN PEMBAHASAN}

Inversi data menggunakan software Res2dinv menghasilkan data distribusi resistivitas lapisan bawah permukaan tanah daerah penelitian. Gambar 4 menunjukkan hasil dari lima line yang berada pada wilayah 1. line AL01 dan AL04 merupakan line yang membentang dari arah Utara ke Selatan. Kedua line tersebut memiliki panjang lintasan sebesar $100 \mathrm{~m}$. line AL01 memiliki lapisan awal berupa batuan yang memililki resistivitas tinggi sekitar 659-1084 Ohm.m. Lapisan bawah permukaan yang memiliki resistivitas rendah sebesar 53-148 Ohm.m berada pada kedalaman 5 meter di bawah permukaan tanah. Lapisan berikutnya memiliki nilai resistivitas yang meningkat seiring peningkatan kedalaman. Sedangkan pada line AL04 nilai resistivitas rendah antara 54179 Ohm.m membentang sepanjang line pada kedalaman 3-7 $\mathrm{m}$ dibawah permukaan tanah. Resistivitas bernilai tinggi pada line ini berada pada lapisan atas yang berupa batuan beku.

Line AL02, AL03, dan AL05 membentang dari Barat ke Timur. Panjang ketiga line tersebut secara berurutan yaitu 65 $\mathrm{m}, 60 \mathrm{~m}$, dan $75 \mathrm{~m}$. Ketiganya membentang diantara line AL01 dan line AL04 sehingga masing-masing line berpotongan dengan kedua line tersebut. Hasil penampang untuk line AL02 yang ditunjukan pada Gambar 4(b) memiliki lapisan bawah permukaan yang didominasi oleh resistivitas tinggi yaitu di atas $420 \mathrm{Ohm} . \mathrm{m}$. Nilai resistivitas rendah yang bernilai $80-152$ Ohm.m. terpusat di posisi $50 \mathrm{~m}$ dari titik awal dengan kedalam sekitar $5 \mathrm{~m}$ dibawah permukaan tanah. Line AL03 didominasi oleh lapisan bawah permukaan dengan nilai resistivitas rendah paling seragam dibanding dengan line lainnya. Nilai resistivitas yang paling mendominasi pada line ini yaitu sebesar 79-200 Ohm.m. Seperti yang tampak pada Gambar 4(c) bahwa lapisan dengan resistivitas rendah membentang pada kedalaman 3-8 m. Kedalaman diatas $8 \mathrm{~m}$ nilai resistivitas akan meningkat seiring bertambahnya kedalaman. line AL5 seperti yang ditunjukan Gambar 4(e) merupakan line yang memiliki nilai resitivitas rendah antara 56-150 Ohm.m. Sedangkannilai resistivitas tinggi pada line ini adalah diatas 1000 Ohm.m yang berada pada lapisan atas dan lapisan di bawah $7 \mathrm{~m}$.

Line AL6, AL8 dan AL10 merupakan line yang memiliki arah yang sama atau sejajar. line AL06 berada diantara line AL08 dan AL10. Gambar 5 (a) menunjukkan hasil inversi data pada line AL06 yang memiliki resistivitas rendah antara 142 Ohm.m sampai 300 Ohm.m. Resistivitas rendah tersebut membentang di bagian Timur pada kedalaman $3 \mathrm{~m}$ dibawah permukaan tanah. Sedangkan bagian Barat didominasi oleh lapisan yang memiliki nilai resistivitas tinggi. line AL08 ditunjukan pada Gambar 5(c) memiliki resistivitas tinggi yaitu diatas 200 Ohm.m yang terdistribusi merata di sepanjang line. Selanjutnya, line AL10 yang ditunjukkan pada Gambar 5(e) memiliki lapisan bawah permukaan yang memiliki resistivitas rendah terpusat pada 55 meter dari titik awal line. Besar resistivitasnya berada pada rentang 47 Ohm.m sampai 200 Ohm.m. Bagian lain dari line ini memiliki resistivitas yang tinggi yaitu diatas 200 Ohm.m. Semakin dalam dan semakin kearah Barat maka nilainya semakin besar.

Line AL07, line AL09, line AL11 memiliki posisi yang sejajar. Ketiga line tersebut memotong lineAL06, AL08 dan AL10 sehingga terdapat beberapa bagian dari line yang sama. Ketiga line membentang dari arah utara (line AL08) ke arah selatan (line AL10). line AL07 dan AL11 merupakan line yang memotong bagian tengah dan barat line AL6, AL8 dan AL10. Berdasarkan Gambar 5(b) dan 5 (f) dapat dilihat dari kedua line tersebut memiliki resistivitas tinggi yang secara berturut turut di atas 212 Ohm.m dan 835 Ohm.m. Keadaan berbeda terjadi pada line AL09 yang memiliki resistivitas rendah pada bagian selatan dengan nilai antara 76-200 Ohm.m.

Line AL1 sampai AL5 merupakan line yang berada di satu wilayah 1. Berdasarkan hasil dari masing-masing line diketahui bahwa wilayah ini memiliki resistivitas lapisan bawah permukaan yang bernilai tinggi. Pada akhir pengolahan data diperoleh hasil berupa gambar penampang 3D dari kelima line tersebut yang ditunjukkan oleh Gambar 6. Pada gambar tersebut masing-masing line dihubungkan sehingga dapat dilihat keseragaman kondisi bawah permukaan. Penggabungan kelima line ini menunjukan bahwa masing-masing line saling berhubungan satu sama lain serta memiliki beberapa bagian yang sama. Berdasarkan gambar tersebut diketahui bahwa wilayah 1 memiliki resistivitas rendah yang bernilai antara 100-500 Ohm.m berada pada kedalaman 5 meter dibawah permukaan tanah.

Selanjutnya Gambar 7 menunjukan gambaran hasil pengolahan data pada wilayah 2. Wilayah ini merupakan gabungan dari line AL06 sampai AL11 Berdasarkan gambar dapat diketahui bahwa wilayah ini memiliki topografi yang cenderung curam serta didominasi oleh resistivitas tinggi yang memiliki nilai $>1000$ Ohm.m. Resistivitas rendah pada wilayah ini terpusat pada bagian tenggara. Bagian tenggara wilayah 2 merupakan bagian yang paling dekat dengan wilayah 1 . Berdasarkan hal tersebut maka lapisan beresistivitas rendah pada wilayah ini merupakan lanjutan dari lapisan resistivitas wilayah 1. 


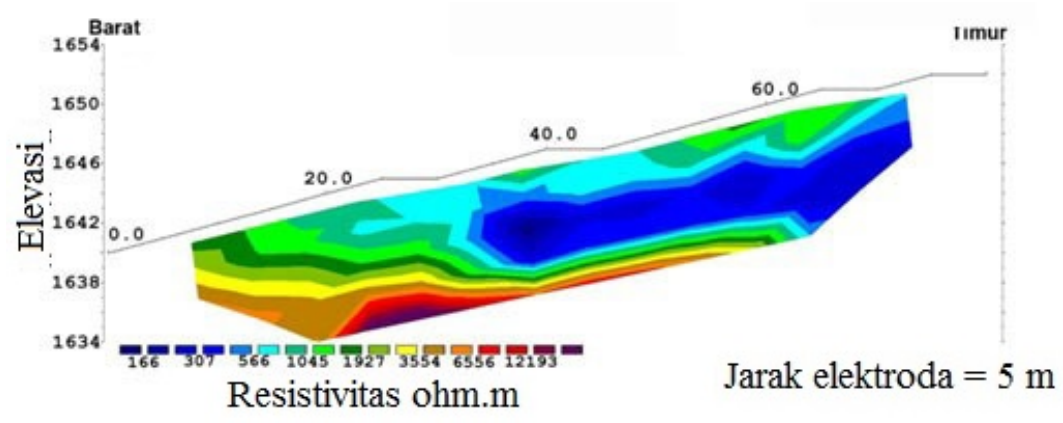

(a) line AL 06

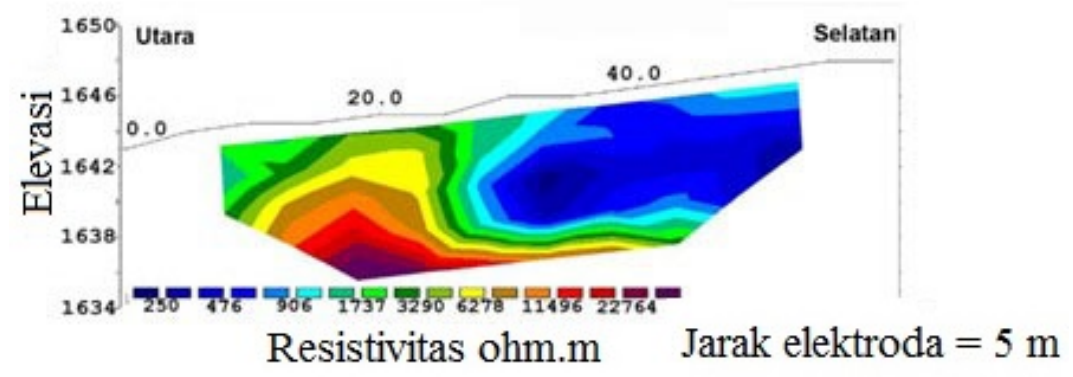

(b) line AL 07

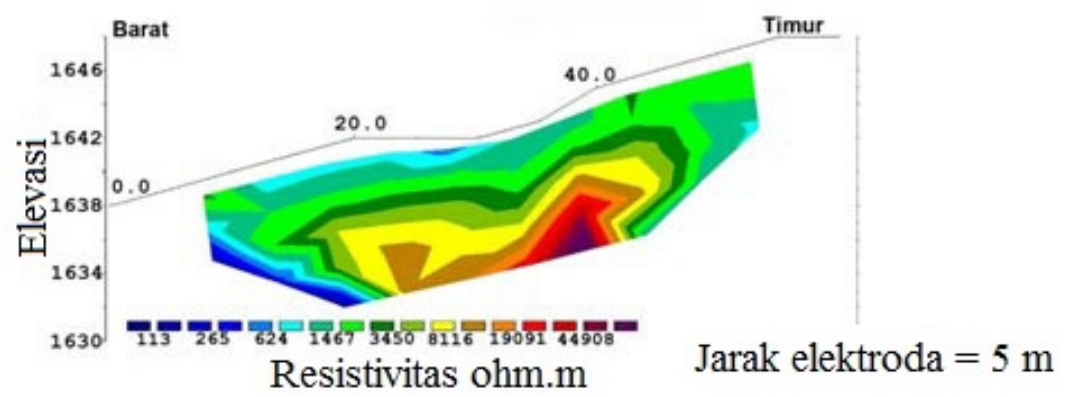

(c) line AL 08

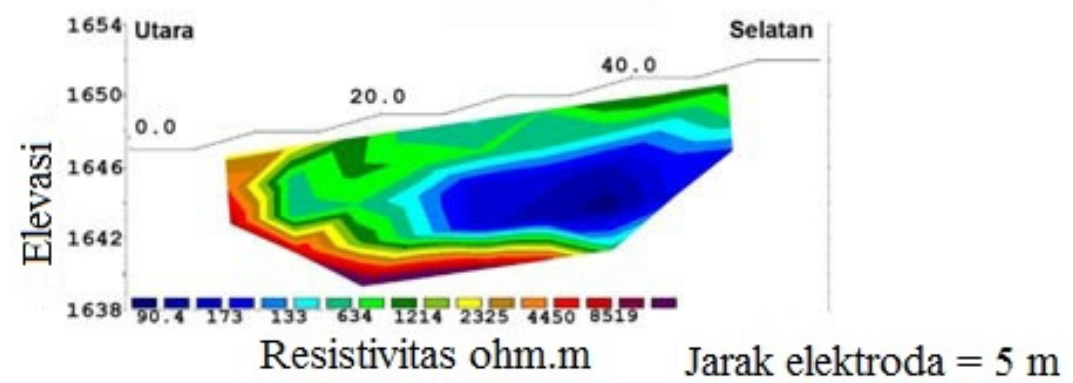

(d) line AL 09

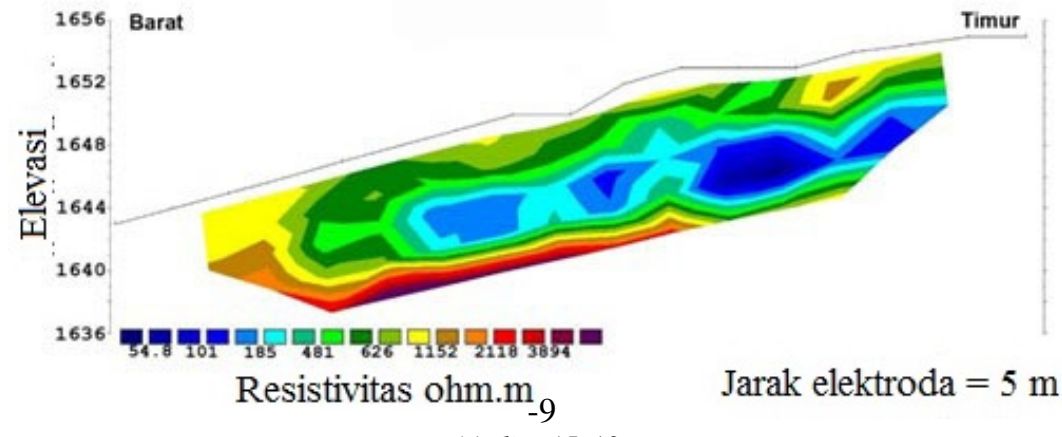

(e) line AL 10
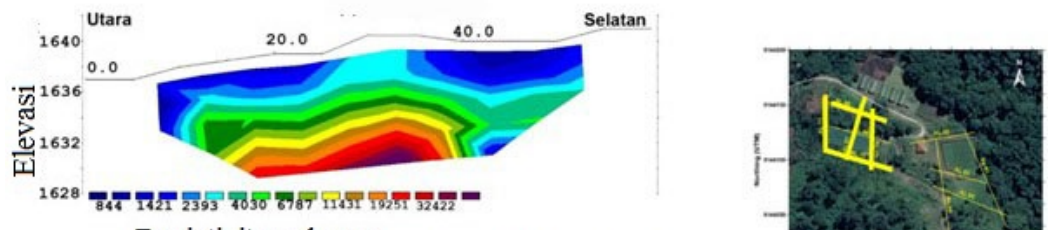


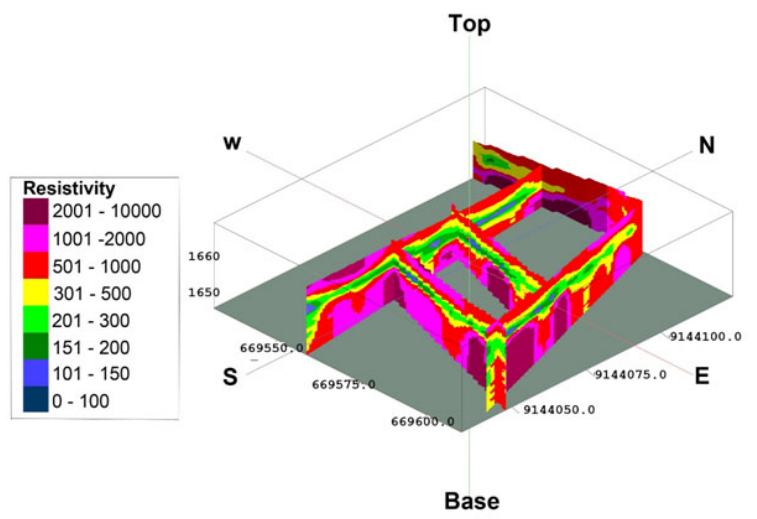

Gambar 6: Penampang 3 dimensi pada wilayah 1.

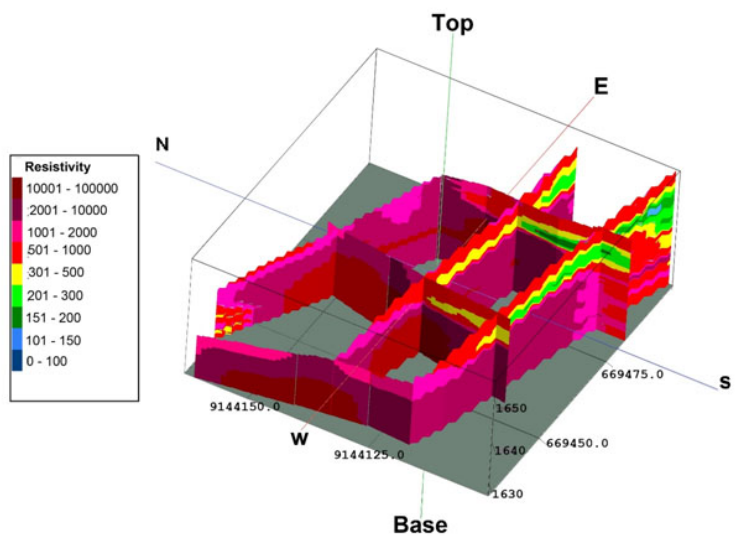

Gambar 7: Penampang 3 dimensi pada wilayah 2.

Secara umum lapisan bawah permukaan wilayah 1 dan wilayah 2 memiliki kondisi yang hampir sama yaitu terdiri dari lapisan batuan yang memiliki resistivitas tinggi $>$ 1000ohm.m. Nilai resistivitas tersebut menunjukkan bahwa kedua wilayah didominasi oleh batuan beku [10]. Hal tersebut didukung oleh kondisi geologi daerah cangar. Berdasarkan hasil model 3D pada Gambar 6 dan Gambar 7 diketahui bahwa nilai resistivitas rendah antara 0-100 ohm.m sangat jarang ditemukan. Rentang resistivitas $>100$ merupakan rentang umtuk lapisan batuan pembawa air [15]. Namun, jika melihat kondisi geologi daerah penelitian maka rentang resistivitas 100-500 ohm.m berpotensi mengandung air [16]. Rentang resistivitas tersebut diduga berupa batuan tuf, basal, andesit, dan olivin. Batuan tersebut diduga berbentuk lapili dan pasiran sehingga memiliki ruang untuk ditempati air. Selain berbentuklapili dan pasiran batuan pada daerah penelitian juga berupa batuan masif. Akan tetapi, mengingat pembentukan batuan daerah penelitian pada masa kuarter yang menyebabkan batuan memiliki celah atau pori yang dapat ditempati air. Air yang menempati celah pada batuan tersebut akan mengakibatkan nilai resistivitas batuan menurun [13]. Jika dibandingkan antara wilayah 1 dan wilayah 2 memiliki perbedaan yang sangat signifikan dikarenakan wilayah 1 cenderung dekat dengan aliran sungai sehingga diduga terjadi rembesan air sungai.

\section{SIMPULAN}

Metode geolistrik resistivitas cukup efektif untuk megetahui petensi air bawah tanah. Berdasarkan hasil penelitian di daerah Agrotechno Park, wilayah 1 merupakan wilayah yang memiliki potesi air tanah rendah dengan nilai resistivitas antara 100-500 Ohm.m sedangkan wilayah 2 cenderung tidak berpotensi air tanah karena didominasi batuan yang memiliki nilai resistivitas tinggi yaitu diatas 1000 Ohm.m.

\section{Ucapan Terima Kasih}

Ucapan terima kasih sebesar-besarnya ditujukan kepada Lembaga Pengelola Dana Pendidikan (LPDP)yang telah mendanai penelitian inidengan Nomor Kontrak PNJ/163/LPDP/ 2016 Tahun 2016. Selain itu, ucapan terima kasih kami tujukan kepada PTUPT RistekDikti No.: 063/SP2H/LT/DPRM/IV/2017 atas dukungan sebagian dana yang dalam rangka pelaksanaan penelitian ini. Ucapan terimakasih juga disampaikan kepada kepada Pusat Studi Energi dan Sumber Daya Alam, Research Center BRAVO ENERGEOBHAS, kepala Agrotechno Park Cangar Universitas Brawijaya, pengelola wisata air panas Cangar yang telah mendukung terlaksananya penelitian ini dan tim Cangar yang membantu proses akuisisi data. Serta kepada rekan-rekan fisika tim akusisi geolistrik Agrotechno Park Cangar yang telah memberi dukungan dalam pengambilan data.
[1] Irjan, "Pemetaan Potensi Air Tanah (Aquifer) Berdasarkan Interpretasi Data Resistivitas Wenner Sounding.", Jurnal Neutrino, vol. 4, no. 2, pp. 201-212, 2012.

[2] O. Anomohanran, "Hydrogeophysical and hydrogeological investigations of groundwater resources in Delta Central, Nigeria", Journal of Taibah University for Science, vol. 129, pp. 108-116, 2017.

[3] A. Kuswoyo, A. Masduqi,'Pemetaan potensi air tanah sebagai sumber air bersih di daerah pesisir pantai batakan kabupaten tanah laut", Jurnal Teknologi \& Industri, vol. 1, no. 3,pp. 1-10, 2014.

[4] A.A. Aning, et al., "Electrical Re sis tiv ity asa Geo physical Map ping Tool; A Case Study Of The New Art Department, KnustGhana.", International Journal of Scientific and Research Publications, vol. 4, no. 1, pp. 1-7, 2014.

[5] A. Jayeoba, M.A. Oladunjoye, "Electrical Resistivity Tomography for Groundwater Exploration in Hard Rock Terrain", International Journal of Science and Technology, vol. 4, no. 4, pp. 
156-163, 2015.

[6] A. Ravindran, M.A.K Prabhu, "Groundwater exploration study using Wenner-Schlumberger electrode array through W-4, 2D resistivity imaging systems at Mahapallipuram, Chennai Tamilnadu", Research Journal of Recent Sciences, vol. 1, no. 11, pp. 36-40, 2012.

[7] G. VenkataRao, P. Kalpana, R. SrinivasaRao, "Biosorption of Malachite Green Dye onto Araucaria cookii Bark: Optimization Using Response Surface Methodology", International Journal of Research in Engineering and Technology, vol. 3, no. 16, pp. 1317, 2014.

[8] S.O. Ariyo, G.O. Adeyemi, "Role of Electrical Resistivity Method for Groundwater Exploration in Hard. Rock Areas: A case Study from Fidiwo/Ajebo Areas of Southwesten Nigeria", The Pacific Journal of Science and Technology, vol. 10, no. 1, pp. 483-486, 2009.

[9] J.E. Chambers, O. Kuras, P.I. Meldrum, R.D. Ogilvy, and J. Hollands, "Electrical resistivity tomography applied to geological, hydrogeological and engineering investigations at a former waste disposal site", Geophysics, vol. 71, pp. 231-239, 2006.

[10] S.Maryanto, Geo Techno Park potential at Arjuno-Welirang Volcano hosted geothermal area, Batu, East Java, Indonesia
(Multi geophysical approach), Proc. 8th International Conference on Global Resource Conservation (2017)

[11] Pusat Sumber Daya Geologi, Survei Terpadu Geologi dan Geokimia Daerah Panas Bumi Gunung Arjuno Welirang Kabupaten Mojokerto, Malang dan Pasuruan, Provinsi Jawa Timur, Departemen Pertammbangan dan Energi, 2010.

[12] S. Santosa, dan T. Suwarti, Geologi Lembar Malang, Departemen Pertambangan dan Energi, 1997.

[13] G. Telford, dan Sheriff, Applied Geophysics, 2nd edition, Cambridge University Press, 1979.

[14] J.N. Sikah, A.A. Aning, S.K. Danuor, E. Manu, C. Okrah, "Groundwater Exploration using 1D and 2D Electrical Resistivity Methods" Journal of Environment and Earth Science, vol. 6, no. 7, pp. 55-63, 2016.

[15] F. Rahmanto, S. Maryanto, A.Susilo, "Tomografi Geolistrik Daerah Sumber Air Panas Cangar, Batu Kompleks ArjunoWelirang", Natural B, vol. 1, no. 2, pp. 188-195, 2011.

[16] C.V. Gopalan, J. Ind. Geophys. Union, ”A comparative study of the groundwater potential in hard rock areas of Rajapuram and Balal, Kasaragod, Kerala”, vol. 15, no. 3, pp. 179-186, 2011. 